\title{
PENGARUH MODEL PEMBELAJARAN BERBASIS PROYEK DAN INQUIRY TERBIMBING TERHADAP KEMAMPUAN LITERASI SAINS BERDASARKAN KEMANDIRIAN BELAJAR (Studi Eksperimen dengan menerapkan pembelajaran berbasis STEM)
}

\author{
Hana Lestari \\ Sahid Entrepreneurial University Bogor, Indonesia \\ hana.lestari@inais.ac.id/hanabiologi@gmail.com
}

\begin{abstract}
Abstrack
The purpose of this reasearch are knowing effect of Self directed learning, PJBL model and Guided Inquiry to science literacy abilities. This study was conducted at SMA Taruna Andigha and SMA Bina Insani in April-May 2018. Design of this research is post-test only experiment and control group design. The method that used on this research was quasi experiment. Experiment class was treated by PJBL model, while control class was treated by Guided Inquiry model. This instruments consist questionnaire of self directed learning and science literacy abilities test. The instruments have been valid and reliable. Analysis data used by Anova 2 ways design (2x2 factorial). The result show that: 1) The ability of science literacy of student who are given PJBL model higher than the students who given Guided inquiry models. (2) There is an enhancement of science literacy of students effected by self directed learning and learning models. (3) The ability of science literacy of students with high self directed learning who given treatment PJBL model is higher than the students who are given Guided inquiry model. (4) There is no significant difference the abiility of science literacy between students low self directed learning who given treatment by PJBL model and students who are given treatment by Guided inquiry model.
\end{abstract}

Keywords: Guided Inquiry model, PJBL model, Self directed learning, The ability of science literacy 


\begin{abstract}
Abstrak
Tujuan penelitian ini adalah untuk mengetahui sejauh mana pengaruh model pembelajaran berbasis proyek dan model inkuiri terbimbing terhadap kemampuan literasi sains siswa berdasarkan kemandirian belajar. Penelitian dilaksanakan di SMA Taruna Andigha dan SMA Bina Insani, dengan subjek penelitian siswa kelas $\mathrm{X}$ yang berjumlah 72 orang. Penelitian ini bertujuan untuk mengetahui pengaruh model PJBL dan model inkuiri terbimbing terhadap kemampuan literasi sains siswa berdasarkan kemandirian belajar. Desain penelitian ini adalah post-test eksperimen dan kontrol grup desain. Metode yang digunakan adalah metode quasi experiment (eksperimen semu). Kelas eksperimen diberikan perlakuan model PJBL, sedangkan kelas kontrol diberi perlakuan model inkuiri terbimbing. Intrumen yang digunakan terdiri atas angket kemandirian belajar dan tes kemampuan literasi sains Instrumen tersebut telah melalui uji validitas dan reliabilitas. Analisis data dilakukan dengan uji Anava dua jalur dengan factorial 2x2. Berdasarkan hasil penelitian, ditemukan bahwa: (1) kemampuan literasi sains siswa yang belajar dengan model PJBL lebih tinggi dibandingkan kemampuan literasi sains siswa yang belajar dengan model inkuiri terbimbing. (2) terdapat interaksi antara kemandirian belajar dan model pembelajaran terhadap kemampuan literasi sains. (3) kemampuan literasi sains siswa yang diberi perlakuan model PJBL lebih tinggi dibandingkan dengan siswa yang diberi perlakuan model inkuiri terbimbing pada kelompok siswa yang memiliki kemandirian belajar tinggi. (4) tidak terdapat perbedaan kemampuan literasi sains siswa yang diberi perlakuan model PJBL dengan siswa yang diberi perlakuan model inkuiri terbimbing pada kelompok siswa yang memiliki kemandirian belajar rendah.
\end{abstract}

Kata kunci: Kemampuan Literasi sains, Kemandirian Belajar, Model Inkuiri Terbimbing, Model PJBL 


\section{A. PENDAHULUAN}

Proses pembelajaran IPA di sekolah menekankan pada pemberian pengalaman langsung untuk mengembangkan kompetensi peserta didik agar lebih memahami alam sekitar. Secara garis besar ilmu pengetahuan alam dapat didefinisikan yang terdiri atas tiga komponen, yaitu sikap ilmiah, proses ilmiah dan produk ilmiah. Dalam kaitannya dengan pembelajaran, hendaknya sains bukan hanya terpaku pada konsep. Akan tetapi memberikan pengalaman langsung dalam pengembang penguasaan produk, proses, dan sikap ilmiah atau lebih luasnya menguasai literasi sains (sains literasi).

Literasi sains (sains literasi) adalah pengetahuan dan pemahaman tentang konsep-konsep ilmiah dan proses yang diperlukan untuk pengambilan keputusan pribadi, partisipasi, dan produktivitas ekonomi (Becker, 2011). Hal ini sangat penting untuk mempersiapkan bekal keterampilan yang harus dimiliki siswa di abad ke 21 dari tingkat sekolah dasar sampai perguruan tinggi. Pentingnya literasi sains karena permasalahan berkaitan dengan pengetahuan dan teknologi. Literasi sains dalam pengukurannya terdiri dari 3 dimensi yaitu konten sains, proses sains dan konteks aplikasi sains.

Pengukuran literasi sains yang dilakukan Programme for International Student Assessment (PISA) pada tahun 2012, menempatkan Indonesia pada urutan terbawah yaitu menempati posisi ke-64 dari 65 negara yang perpartisipasi (OECD,2015). Sedangkan hasil PISA tahun 2015 menunjukan grafik peningkatan. Dari 72 negara yang berpartisipasi, Indonesia menempati urutan ke-8 dari bawah. Terjadi peningkatan skor kompetensi sains dari 382 pada 2012 menjadi 403 pada 2015. Pengukuran literasi yang dilaksanakan oleh PISA digunakan antara lain untuk membandingkan literasi membaca, matematika dan sains siswa-siswa suatu negara dengan negara peserta lain, memahami kekuatan dan kelemahan sistem pendidikan masing-masing negara. Hasil nilai sains yang di peroleh Indonesia baik tahun 2012 ataupun 2015, masih dibawah rata-rata 500 dari nilai yang ditetapkan PISA. Indonesia hanya mencapai Low Internasional Bencmark.

Rendahnya literasi sains siswa di Indonesia disebabkan oleh beberapa faktor diantaranya: (1) Lemahnya pemahaman siswa terhadap 
konsep dasar sains; (2) Siswa hanya mempelajari sains sebatas teori saja siswa belum mampu mengaplikasikan konsep sains dalam kehidupan sehari-hari; (3) Lemahnya siswa dalam mengungkapkan pikiran dalam bentuk tulisan dan menghubungkan informasi-informasi dalam teks bacaan; (4) Rendahnya kemampuan siswa dalam membaca, menginterpretasikan data dalam bentuk gambar, tabel, diagram dan bentuk penyajian lainnya; (5) Rendahnya kemampuan siswa dalam berpikir tingkat tinggi seperti memecahkan permasalahan, bernalar ilmiah, berpikir kritis dan berpikir kreatif (Rustaman, 2006).

Bagian yang tidak dapat dipisahkan dari sains adalah teknologi. Perkembangan teknologi dilandasi oleh sains sedangkan teknologi itu sendiri menunjang perkembangan sains, terutama digunakan untuk aktivitas penemuan dalam upaya memperoleh penjelasan tentang obyek dan fenomena alam. Beberapa hasil rujukan menunjukan bahwa pembelajaran sains dalam konteks teknologi sangat potensial meningkatkan literasi sains. Upaya yang dapat dilakukan adalah salah satunya dengan penggunaan pembelajaran STEM.

Sebagai sebuah tren yang sedang berkembang didalam dunia pendidikan. Pembelajaran STEM digunakan untuk mengatasi situasi dunia nyata melalui sebuah desain berbasis proses pemecahan masalah seperti yang digunakan oleh para ilmuwan. Beberapa manfaat STEM ialah membuat siswa menjadi pemecah masalah, penemu, innovator, mampu mandiri, pemikir yang logis, melek teknologi, mampu menghubungkan budaya dan sejarahnya dunia pendidikan, dan mampu menghubungkan STEM dengan dunia kerja. Penerapan STEM dapat didukung oleh berbagai model pembelajaran untuk meningkatkan literasi sains, salah satunya adalah model pembelajaran berbasis proyek dan inkuiri terbimbing (Morrison, 2006).

Model pembelajaran berbasis proyek merupakan pembelajaran inovatif yang menekankan pada kegiatan kompleks dengan tujuan pemecahan masalah berdasarkan kegiatan inkuiri dan menghasilkan produk (Bell, 2010). Produk yang dihasilkan dapat menjadi kontribusi siswa terhadap peningkatan kualitas kehidupan. Proses penyelesaian masalah dalam kehidupan dan pembuatan produknya dapat dikerjakan secara individu maupun kelompok. Pengerjaan secara 
berkelompok dapat mendorong siswa untuk bekerja sama namun tetap bertanggung jawab atas pekerjaannya secara mandiri. Melalui pembelajaran berbasis proyek, siswa memiliki literasi sains dan teknologi yang nampak dari membaca, menulis, mengamati, serta melakukan sains sehingga dapat dijadikan bekal untuk hidup bermasyarakat dan memecahkan permasalahan yang dihadapi dalam kehidupan sehari-hari yang terkait dengan bidang ilmu STEM (Capraro, 2015).

Adapun model lain yang dipadukan yaitu model inkuiri terbimbing. Model inkuiri terbimbing dipandang cocok diterapkan dalam pembelajaran IPA karena dapat mendorong siswa untuk semakin berani dan kreatif dan bukan saja untuk mengerti materi pelajaran tetapi mampu menciptakan penemuan.

Model pembelajaran inkuiri terbimbing dalam pembelajaran sains menuntut siswa untuk menemukan konsep-konsep sains berdasarkan hasil analisa mengenai fenomena alam yang diamati. Model pembelajaran ini memberikan ruang yang cukup luas untuk siswa dalam mengeksplorasi kemampuannya dalam pembelajaran. Pembelajaran inkuiri menurut Carlson (2008), inkuiri terbimbing dapat mengembangkan keterampilan intelektual dan berpikir kritis siswa serta siswa mampu memecahkan masalah secara ilmiah.

Kemampuan literasi sains siswa tidak hanya dipengaruhi oleh model pembelajaran yang diterapkan oleh guru saja, namun juga kemampuan siswa dalam mengatur cara belajarnya yang baik dan efisien. Menurut Briesen (2011), kemampuan siswa dalam mengatur cara belajarnya dengan baik dan efisien ini disebut kemandirian belajar. Kemandirian belajar merupakan aktivitas belajar yang didorong oleh kemauan sendiri, pilihan sendiri dan tanggung jawab sendiri tanpa bantuan orang lain serta mampu mempertanggung jawabkan tindakannya (Cantwell \& Archer, 2002). Siswa dikatakan telah mampu belajar secara mandiri apabila ia telah mampu melakukan tugas belajar tanpa ketergantungan dengan orang lain. Siswa yang memiliki kemandirian belajar yang baik mampu menemukan strategi pembelajaran yang tepat dan efisien, mampu mendapatkan pengetahuan dari sumber-sumber yang digunakan, serta mampu memotivasi diri 
untuk terus memahami materi yang dipelajari. Siswa yang memiliki kemandirian belajar yang baik juga memiliki kemampuan literasi sains yang baik, (Gibbons, 2002).

Dalam pembelajaran, guru dapat menggunakan model yang sesuai dan berpengaruh untuk meningkatkan kemandirian belajar dan kemampuan literasi siswa. Tingginya tingkat kemandirian belajar siswa diharapkan dapat meningkatkan kemampuan literasi sains siswa. Model pembelajaran berbasis proyek dan inquiry terbimbing diharapkan dapat memiliki pengaruh pada kemampuan literasi sains siswa. Model pembelajaran berbasis proyek dan inkuiry terbimbing memiliki tahapan yang menekankan keterampilan proses sains siswa sehingga melatih siswa untuk memiliki kemandirian belajar, berpikir kritis, dan analisis dalam memecahkan masalah secara ilmiah. Oleh karena itu diperlukan adanya suatu penelitian untuk mengetahui pengaruh model berbasis proyek dan inquiri terbimbing terhadap kemampuan literasi sains siswa berdasarkan kemandirian belajar.

\section{B. METODE}

Metode penelitian yang digunakan dalam penelitian ini adalah metode kuasi eksperimen desain faktorial 2X2. Penelitian ini mempunyai 3 variabel dimana variabel bebas $(\mathrm{X})$ yaitu terdiri dari Model pembelajaran (X1) dan Kemandirian belajar (X2). Sedangkan variabel terikat $(\mathrm{Y})$ yaitu Literasi sains. Kelas eksperimen akan diberi perlakuan model pembelajaran berbasis proyek, sedangkan kelas kontrol diberi perlakuan model inkuri terbimbing. Sebelum diberi perlakuan dengan model, siswa akan diberi kuisioner kemandirian belajar terlebih dahulu. Desain penelitian yang digunakan di dalam penilitian ini adalah Post test Only Control Design dengan faktorial 2x2.

Tabel 1. Desain Penelitian dengan Faktorial 2 x 2

\begin{tabular}{|l|c|c|}
\hline \multirow{2}{*}{$\begin{array}{c}\text { Motivasi } \\
\text { (B) }\end{array}$} & \multicolumn{2}{|c|}{ Model Pembelajaran (A) } \\
\cline { 2 - 3 } & PJBL (A1) & Inkuiri Terbimbing (A2) \\
\hline Tinggi (B1) & A1B1 & A2B1 \\
\hline Rendah (B2) & A1B2 & A2B2 \\
\hline
\end{tabular}


Populasi target pada penelitian ini adalah seluruh siswa kelas X di Kota Bogor tahun pelajaran 2017/2018. Populasi terjangkau pada penelitian ini adalah dari 8 SMA di Bogor Tengah, secara random sampling dipilih 2 SMA, yaitu SMA Taruna Andigha dan SMA Bina Insani pada semester genap tahun ajaran 2017/2018. Sampel diambil dari populasi terjangkau secara random sampling, dari 4 kelas X dipilih 2 kelas dari masing-masing sekolah. Kemudian dari tiap kelas baik kelas eksperimen maupun kelas kontrol dipilih $27 \%$ siswa yang memiliki kemadirian belajar tinggi dan $27 \%$ siswa yang memiliki kemadirian belajar rendah.

Pada akhir penelitian akan diberikan tes yang sama, yaitu dengan diberikan tes kemampuan literasi sains siswa. Instrumen yang digunakan dalam penelitian ini telah diuji validitas dan reliabilitasnya oleh ahli. Data yang dieproleh dari instrument ini kemudian akan diuji menggunakan uji hipotesis jenis ANOVA dua jalur. Setelah sebelumnya melalui uji prasyarat analisis, yaitu uji normalitas, homogenitas, dan kesamaan rata-rata

\section{HASIL DAN PEMBAHASAN}

Data skor kemampuan literasi sains dan kemandirian belajar antara siswa yang diberi perlakuan model PJBL dan siswa yang diberi model Inquiry Terbimbing:

Tabel 2. Rekapitulasi Skor Literasi Sains Siswa pada Berbagai Kelas

\begin{tabular}{|c|c|c|c|c|}
\hline \multirow{2}{*}{$\begin{array}{c}\text { Rentang Skor Literasi } \\
\text { Sains }\end{array}$} & \multicolumn{4}{|c|}{ Frekuensi Relatif Siswa } \\
\cline { 2 - 5 } & A1B1 & A1B2 & A2B1 & A2B2 \\
\hline $6-6,5$ & $0 \%$ & $0 \%$ & $0 \%$ & $44 \%$ \\
\hline $6,5-7$ & $0 \%$ & $11 \%$ & $0 \%$ & $55 \%$ \\
\hline $7-7,5$ & $17 \%$ & $33 \%$ & $11 \%$ & $0 \%$ \\
\hline $7,5-8$ & $11 \%$ & $55 \%$ & $33 \%$ & $0 \%$ \\
\hline $8-8,5$ & $27 \%$ & $0 \%$ & $44 \%$ & $0 \%$ \\
\hline $8,5-9$ & $33 \%$ & $0 \%$ & $11 \%$ & $0 \%$ \\
\hline $9-9,5$ & $11 \%$ & $0 \%$ & $0 \%$ & $0 \%$ \\
\hline Rerata Skor & 8,5 & 7,4 & 8,1 & 6,5 \\
\hline Skor tertinggi & 9,25 & 8 & 9 & 7 \\
\hline Skor Terendah & 7,25 & 6,5 & 7 & 6 \\
\hline
\end{tabular}


Berdasarkan tabel 2, menunjukkan bahwa rata-rata skor kemampuan literasi sains siswa yang diberi perlakuan model PJBL sebesar 7,95 sedangkan rata-rata skor kemampuan literasi sains siswa yang diberi perlakuan model inkuiri terbimbing sebesar 7,25. Maka dapat disimpulkan bahwa kemampuan literasi sains siswa yang diberi perlakuan model PJBL lebih tinggi daripada kemampuan literasi sains siswa yang diberi perlakuan model inkuiri terbimbing.

Uji hipotesis data kemampuan literasi sains dengan menggunakan model PJBL dan model inkuiri terbimbing serta kemandirian belajar dilakukan dengan uji anava 2 arah dapat dilihat pada tabel 3 .

Tabel 3. Tabel Uji Hipotesis Anava 2 Arah

\begin{tabular}{|c|c|c|c|c|}
\hline Source & Df & Mean Square & $\mathrm{F}$ & Sig. \\
\hline Corrected Model & 3 & 5.787 & 19.382 & .000 \\
\hline Intercept & 1 & 1977.124 & 6622.350 & .000 \\
\hline Model & 1 & 3.346 & 11.206 & .002 \\
\hline Kemandirian Belajar & 1 & 13.830 & 46.324 & .000 \\
\hline Model * Kemandirian Belajar & 1 & .287 & .961 & .032 \\
\hline Error & 30 & .299 & & \\
\hline Total & 34 & & & \\
\hline Corrected Total & 33 & & & \\
\hline
\end{tabular}

Hasil analisis ANAVA dua jalur pada tabel 3 menunjukkan bahwa siswa yang diberikan perlakuan model PJBL dan model Inkuiri terbimbing memperoleh nilai signifikansi $=0.002$, maka $0.002 .<0,05$ atau Ho ditolak. Maka dapat dikatakan bahwa terdapat perbedaan yang signifikan pada kemampuan literasi sains siswa jika dikelompokkan berdasarkan kemandirian belajar. Hasil ini membuktikan hipotesis penelitian yang pertama yaitu terdapat pengaruh model pembelajaran terhadap kemampuan literasi sains siswa. 
Dari hasil perhitungan juga diperoleh bahwa nilai signifikansi untuk nilai interaksi antara model pembelajaran dengan kemandirian belajar adalah 0.032 , nilai $\mathrm{p}<0.05$ berarti tolak $\mathrm{H}_{0}$ yang menunjukkan bahwa terdapat interaksi antara model pembelajaran dengan kemandirian belajar. Hasil ini membuktikan hipotesis kedua yakni terdapat interaksi model pembelajaran dan tingkat kemandirian belajar terhadap kemampuan literasi sains siswa, dengan demikian kemandirian belajar yang dimiliki siswa mempengaruhi kemampuan literasi sains siswa, dan apabila diberikan perlakuan model pembelajaran yang berbeda, yaitu dengan model PJBL dan model inkuiri terbimbing, maka juga mempengaruhi kemampuan literasi sains yang dimiliki siswa. Hal ini bisa terlihat dari Gambar 1 dibawah ini.

\section{Estimated Marginal Means of Tes Kemampuan Literasi Sains}

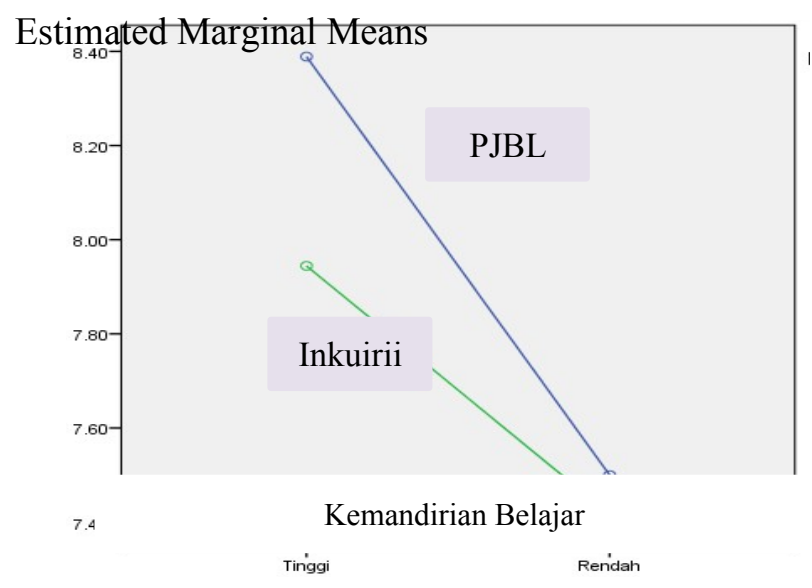

Gambar 1. Interaksi antara model pembelajaran dan kemandirian belajar

Berdasarkan gambar 1 menunjukkan bahwa terdapat interaksi antara kemandirian belajar dan model pembelajaran. Siswa yang memiliki kemandirian belajar rendah ketika diberi perlakuan model PJBL maupun model inkuiri terbimbing, tidak akan mempengaruhi kemampuan literasi sains yang dimiliki. Semakin tinggi kemandirian belajar maka akan semakin tinggi hasil kemampuan literasi sains yang dimiliki, terutama kelompok siswa yang diberi perlakuan model PJBL. Siswa dengan kemandirian belajar tinggi yang diberi perlakuan model 
PJBL akan memiliki kemampuan literasi sains yang lebih tinggi jika dibandingkan dengan siswa dengan kemandirian belajar tinggi yang diberi perlakuan model inkuiri terbimbing.

Hasil analisis data hipotesis ketiga menunjukkan bahwa kemampuan literasi sains siswa yang diberi perlakuan model PJBL lebih tinggi dibandingkan dengan kemampuan literasi sains siswa yang diberi perlakuan dengan model inkuiri terbimbing pada siswa yang memiliki kemandirian belajar tinggi. Hasil analisis data hipotesis keempat menunjukkan tidak terdapat perbedaan kemampuan literasi sains siswa antara kelompok siswa yang diberi pelakuan dengan model PJBL dan model inkuiri terbimbing pada siswa yang memiliki kemandirian belajar rendah.

\section{SIMPULAN}

Berdasarkan hasil dari pengujian hipotesis dan pembahasan penelitian, maka dapat disimpulkan bahwa: (1) Kemampuan literasi sains siswa yang belajar dengan model PJBL lebih tinggi daipada kemampuan literasi sains siswa yang belajar dengan model pembelajaran inkuiri terbimbing. Hal ini disebabkan karena terdapat perbedaan langkah-langkah dalam proses pembelajaran. (2) Terdapat interaksi antara kemandirian belajar dengan model pembelajaran terhadap kemampuan literasi sains, yaitu terdapat pengaruh pada kemampuan literasi sains siswa pada penerapan model pembelajaran dan kemandirian belajar siswa yang berbeda tingginya. (3) Kemampuan literasi sains siswa yang diberi perlakuan Model PJBL lebih tinggi dibandingkan dengan siswa yang diberi perlakuan model inkuiri terbimbing, pada kelompok siswa yang memiliki kemandirian belajar tinggi dikarenakan perbedaan pada penerapan tahapan menyelesaikan masalah selama pembelajaran berlangsung. (4) Tidak terdapat pengaruh terhadap kemampuan literasi sains pada siswa yang memiliki kemandirian belajar rendah yang diberi perlakuan Model PJBL maupun siswa model pembelajaran inkuiri terbimbing. 


\section{DAFTAR PUSTAKA}

Becker, K.H. \& Park, K. 2011. Integrative Approaches among Science Technology, Egineering, and Mathematics (STEM) Subject on Students Learning: Meta-Analysis. Journal of STEM Education: Innovation and Research, Vol.12(5):23.

Bell, R., Smetana \& Binns. 2005. "Simplifying Inquiry Instruction: Assesing The Inquiry Level of Classroom Activities", The Science Teacher, Vol.72 (7):55.

Bell, S. 2010. Project Based Learning for the 21 th Century: Skills for the Future, The Clearing House, Vol. 83: 39.

Brookfield, Stephen. 2000. Understanding and Facilitating Adult Learning. San Fransisco : Bass Publisher.

Bybee, Ryan, Mc Craen dan Laurie. 2009. PISA 2006: An Assesment of scientific Literacy". Journal of Reseach in Science Teaching, Vol. 46(8): 865.

Carlson, J.L. 2008. Effect of Theme Based Guided Inquiry Instructio on Science. Washington DC: Michigan Technological University.

Cantwell R.H, \& Archer, J. 2002. The Validation of Measures of SelfEfficacy, Motivation and self-Regulated Learning among Thai tertiary Students. Paper presented at the Annual Conference of the Australian Association for Research in Education.

Geraldin, Monalisa. 2015. Pengaruh Model Pembelajaran dan Kemampuan Berpikir Kritis Terhadap Kemampuan Literasi Sains Siswa. Jakarta: Universitas Negeri Jakarta, h.4.

Gibbons, M. 2002. The Self Directed Learning Handbook: Challenging Adolescent Student to Excel. San Fransisco: CA: Jossey Bass.

Hans, Capraro, \& Capraro, M. M. 2015. "How science, technology, engineering, and mathematics (STEM) project-based learning (PBL) affects high, middle, and low achievers differently: The Impact of student factors on achievement". International Journal of Science and Mathematics Education, Vol.13(5):1089.

I.O Matthew and Kenneth. 2012. A Study on The Effect of Guided Learning Teaching Method on Students Achievement in Logic. International Researcher, Vol 2(1):135. 
Jin G. \& Bierma, T.J. 2011. "Guided Inquiry Learning in Environmental Health", Journal of Environmental Health, Vol.73 (6):80.

Knowles, M. Holton E., dan Swanson R. 2011. The Adult Learner: The Definitive Classic in Adult Education and Human Resource Development. Houston: Gulf Publishing Company.

Liu, "Beyond Science Literacy: Science and the Public",International Journal of Environmental \& Science Education, Vol. 4(3),2009,h.303.

Mayasari, Kadorahman \& Rusdiana. 2015. Pengaruh pembelajaran terintegrasi science, technology, engineering, and mathemathics (STEM) pada hasil belajar peserta didik: Studi meta analisis, Prosiding Semnas Pensa VI "Peran Literasi Sains". Surabaya: UNESA, h.376.

Matthew M.B. \& Igharo O.K. 2013. "A Study On The Effect of Guided Inquiry Teaching Method on Students Achievment in Logic", International Researcher, Vol.2: 136.

M. Jeanne, Van Briesen. 2011. Self Directed Learning. Departement of Civil and Evironmental Engineering : Caenegie Mellon University.

Morrison J. 2006. "TIES STEM Education Monograph Series: Atributes of STEM Education”. Baltimore,MD:TIES, (2): 5.

OECD. 2012. PISA 2012 Results in Focus What 15-year-olds know and what they can do with what they knowh. h.5.

Rustaman. 2006. Literasi Sains Anak Indonesia. Bandung: FPMIPA UPI.

Rush, D. Laboy. 2017. Integrated STEM Education thought ProjectBased

Learning,http://www.learning.com/stem/whitepaper/Integrate d STEM Education thought Project-Based Learning (diakses 16 Desember 2017). 